\title{
PENGARUH PEMBERIAN PROBIOTIK Bacillus spp. MELALUI PAKAN TERHADAP KELANGSUNGAN HIDUP DAN LAJU PERTUMBUHAN IKAN NILA (Oreochromis niloticus)
}

\author{
Muhammad Masyarul Rusdani ${ }^{1)}$; Sadikin Amir ${ }^{1)}$; Saptono Waspodo ${ }^{1)}$; Zaenal Abidin ${ }^{1)}$ \\ ${ }^{1)}$ Dosen Program Studi Budidaya Kelautan Program Vokasi-Universitas Mataram \\ mm.rusdani@unram.ac.id
}

\begin{abstract}
ABSTRAK
Penelitian ini bertujuan untuk menguji kinerja bakteri probiotik Bacillus spp. dan prebiotik molase dengan dosis berbeda terhadap tingkat kelangsungan hidup dan kinerja pertumbuhan ikan nila (Oreochromis niloticus). Penelitian ini menggunakan motede eksperimen dengan rancangan acak lengkap (RAL) dan melibatkan 5 perlakuan, yaitu kontrol (K), Bacillus spp. $10 \mathrm{ml} / \mathrm{kg}$ pakan (A); Bacillus spp. 10 $\mathrm{ml} / \mathrm{Kg}$ pakan + molase $10 \mathrm{v} / \mathrm{v}$ (B); Bacillus spp. $20 \mathrm{ml} / \mathrm{Kg}$ pakan (C); dan Bacillus spp. $20 \mathrm{ml} / \mathrm{Kg}$ pakan + molase $10 \mathrm{v} / \mathrm{v}(\mathrm{D})$. Hasil yang diperoleh menunjukkan variasi untuk total bakteri, yaitu dari $2,24 \times 10^{8}$ hingga $3,78 \times 10^{8} \mathrm{CFU} / \mathrm{ml}$. Demikian juga dengan total Bacillus spp. dari $1,07 \times 10^{6}$ hingga $2,02 \times 10^{7}$ $\mathrm{CFU} / \mathrm{ml}$. Adapun untuk pengamatan tingkat kelangsungan hidup dan laju pertumbuhan tidak menunjukkan hasil yang signifikan. Meski demikian, perlakuan D memiliki hasil yang relatif lebih baik dengan nilai SR dan LPH berturut-turut 96,67\% dan 1,01 \%/hari.
\end{abstract}

Kata kunci : probiotik Bacillus spp., prebiotik molase, total bakteri dan Bacillus spp., tingkat kelangsungan hidup, laju pertumbuhan harian

\begin{abstract}
This study was aimed to determine the good combination of probiotic bacillus spp. and prebiotic molasses with different doses to survival rate and growth performance of tilapia (Oreochromis niloticus). this study has used experimental design with completely randomized design (CRD) and five treatment, i.e. Control (K), without probiotic and prebiotic; Bacillus spp. $10 \mathrm{ml} / \mathrm{kg}$ feed (A); Bacillus spp. $10 \mathrm{ml} / \mathrm{Kg}$ feed + molasses $10 \mathrm{v} / \mathrm{v}$ (B); Bacillus spp. $20 \mathrm{ml} / \mathrm{Kg}$ feed (C); dan Bacillus spp. $20 \mathrm{ml} / \mathrm{Kg}$ feed + molasses $10 \mathrm{v} / \mathrm{v}$ (D). The results showed variation for total bacteria and total Bacillus spp. The average of total bacteria obtained in this study ranged from $2,24 \times 10^{8}$ to $3.78 \times 10^{8} \mathrm{CFU} / \mathrm{ml}$. Likewise, the total Bacillus spp. were obtained from $1.07 \times 10^{6}$ to $2.02 \times 10^{7} \mathrm{CFU} / \mathrm{ml}$. While for survival rate (SR) and the growth rate (DGR) did not showed significant results. However, treatment D has a relatively better then treatment else with SR and DGR respectively $96.67 \%$ and $1.01 \%$.day ${ }^{-1}$.
\end{abstract}

Keywords : probiotic Bacillus spp., prebiotic molasses, total bacteria and Bacillus spp., survival rate, specific growth rate. 


\section{PENDAHULUAN}

Ikan nila (Oreochromis niloticus) merupakan komoditas perikanan yang banyak digemari oleh masyarakat dari berbagai kalangan. Hal ini mendorong peningkatan produksi ikan nila agar permintaan pasar dapat terpenuhi. Peningkatan produksi ikan nila akan berdampak pada meningkatnya kebutuhan pakan yang digunakan. Bahan pakan yang umum digunakan sebagai sumber protein yaitu tepung bungkil kedelai dan tepung ikan. Khusus di Indonesia, sebagian besar bahan baku pakan $(70-80 \%)$ berasal dari luar negeri (Hadadi et al. 2010).

Harga pakan buatan yang relatif mahal disebabkan karena tingginya kandungan protein dalam pakan dan bahan baku yang masih mengandalkan dari bahan-bahan import. Sumber-sumber protein dalam pakan seperti tepung ikan dan kedelai, harganya semakin mahal dan ketersediaannya semakin berkurang. Sifat fisiologis ikan menjadikannya lebih efektif dalam memanfaatkan protein sebagai sumber energi dibandingkan karbohidrat (Furuichi 1988). Kecernaan karbohidrat pada ikan relatif rendah karena ketersediaan dan aktivitas enzim amylase dalam saluran pencernaan ikan yang rendah dibandingkan dengan hewan terrestrial dan manusia.

Oleh karena itu, perlu dilakukan berbagai upaya peningkatan aktivitas enzim amylase sehingga penggunaan protein sebagai sumber energi dapat dikurangi dan pemanfaatan karbohidrat sebagai sumber energi dapat ditingkatkan. Salah satu upaya tersebut adalah dengan meningkatkan ketersediaan amylase dalam saluran pencernaan ikan melalui pemberian probiotik.

Probiotik merupakan mikroba hidup atau yang telah dimatikan atau komponen mikroba yang memberikan keuntungan bagi inangnya (Lazado \& Caipang 2014). Probiotik merupakan mikroba hidup yang ketika diberikan dalam jumlah cukup dapat memberikan pengaruh menguntungkan bagi kesehatan inang dan dapat meningkatkan keseimbangan mikroba dalam saluran pencernaan (Nayak 2010). Beberapa studi melaporkan bahwa probiotik dapat meningkatkan kinerja pertumbuhan dan respons imun ikan nila (Wang et al. 2008), serta tingkat kelangsungan hidup dan aktivitas enzim pencernaan larva Penaeus vannamei (Zhou et al. 2009).
Bakteri probiotik yang digunakan dalam penelitian ini adalah Bacillus spp.

Nayak (2010) menyatakan bahwa dosis probiotik umumnya bervariasi dari $10^{6}-10^{10} \mathrm{CFU} / \mathrm{g}$ pakan. Dosis optimum probiotik dapat bervariasi tergantung dari jenis inang dan tingkat kekebalan tubuhnya. Menurut Minelli dan Benini (2008) dosis probiotik dapat menjadi faktor pembatas untuk memberikan pengaruh menguntungkan bagi inang. Oleh sebab itu penelitian ini bertujuan untuk menguji kinerja bakteri probiotik Bacillus spp. dan prebiotik molase dengan dosis berbeda terhadap tingkat kelangsungan hidup dan kinerja pertumbuhan ikan nila (Oreochromis niloticus).

\section{METODOLOGI}

\section{Waktu dan Tempat}

Penelitian ini akan dilaksanakan pada sejak bulan Oktober hingga Desember 2015 di Desa Lingsar Kecamatan Lingsar Kabupaten Lombok Barat dan laboratorium Program Studi Budidaya Perairan Universitas Mataram.

\section{Alat dan Bahan}

Alat

Alat yang digunakan dalam penelitian ini antara lain : water quality checker (DO, $\mathrm{pH}$ dan suhu); blower; timbangan digital (analitik); set-alat pertukangan; waring; dan lain-lain.

Bahan

Bahan yang digunakan dalam penelitian ini antara lain : pakan HI PRO VITE 779 ®; probiotik Bacillus spp.; molase; ikan nila (Oreochromis niloticus) ukuran $3-5 \mathrm{~cm}$ dan lain-lain.

\section{Prosedur Penelitian}

Ikan yang digunakan dalam penelitian ini adalah ikan nila dengan ukuran 3-5 cm/ekor yang dipelihara sebanyak 15 ekor dalam warring berukuran $50 \times 50 \times 50 \mathrm{~cm}$ untuk setiap unit percobaan. Pakan diberikan sebanyak 5\% per sehari dari bobot biomassa (08.00 wita dan 17.00 wita). Pakan yang diberikan adalah pakan komersil (HI PRO VITE 779 ()) dengan kandungan protein 30-32\%. Sebelum diberikan, pakan terlebih dahulu ditambahkan dengan 
probiotik Bacillus spp. $10^{6} \mathrm{CFU} / \mathrm{ml}$ sesuai dengan dosis yang diujikan, yaitu sebagai berikut :

1. Pakan tanpa penambahan probiotik (Kontrol / K)

2. Pakan + Probiotik Bacillus spp. $10 \mathrm{ml} / \mathrm{Kg}$ pakan

3. Pakan + Probiotik Bacillus spp. $10 \mathrm{ml} / \mathrm{Kg}$ pakan + molase $10 \mathrm{v} / \mathrm{v}$ probiotik

4. Pakan + Probiotik Bacillus spp. $20 \mathrm{ml} / \mathrm{Kg}$ pakan

5. Pakan + Probiotik Bacillus spp. $20 \mathrm{ml} / \mathrm{Kg}$ pakan + molase $10 \mathrm{v} / \mathrm{v}$ probiotik

Setelah 45 hari pemeliharaan, perlakuan uji selanjutnya dianalisis untuk menentukan perlakuan terbaik.

\section{Parameter Pengamatan}

\section{Total Bakteri Total dan Bacillus spp. di Usus}

Kemampuan bakteri probiotik dalam mendominasi pada saluran pencernaan ditentukan berdasarkan jumlah bakteri Bacillus spp. yang ada di usus yang telah diberi penanda rifampisin. Organ usus diambil sebanyak 1 gram kemudian digerus sampai homogen dalam $9 \mathrm{ml}$ larutan PBS (Phosphate Buffer Saline). Setelah homogen dengan larutan PBS, diambil sebanyak 0,1 gram kemudian dilakukan pengenceran bertingkat pada $0,9 \mathrm{ml}$ PBS dan disebar dalam cawan petri sebanyak $50 \mu \mathrm{l}$ dan disebar merata menggunakan batang penyebar pada media TSA (Trypticase Soy Agar) yang telah ditambahkan rifampisin dengan dua ulangan dan diinkubasi selama 24 jam. Jumlah koloni bakteri Bacillus spp. dihitung berdasarkan rumus :

Keterangan:

$$
T B C=\frac{K}{A \times B}
$$

TBC : Total Bacterial Count $(\mathrm{cfu} / \mathrm{ml})$

$\mathrm{K}$ : Jumlah koloni

A : Volume inokulasi dalam media pengencer (ml)

B : Pada pengenceran keberapa kolonibakteri dihitung

Pengukuran jumlah bakteri di usus dilakukan pada hari ke-45 pemeliharaan. Pengukuran dilakukan untuk mengetahui efektivitas pemberian probiotik dan sinbiotik (probiotik+prebiotik), dalammenstimulir pertumbuhan bakteri dalam usus. Cara kerja untuk perhitungan koloni bakteri di usus dengan menumbuhkannya dalam media TSA (Tryptone Soya Agar) (Safitri 2010).

\section{Tingkat Kelangsungan Hidup Ikan}

Tingkat kelangsungan hidup ikan (Survival Rate / $S R$ ) dihitung dari persentase jumlah ikan yang hidup di akhir masa pemeliharaan dibanding dengan jumlah ikan pada saat tebar awal. Tingkat kelangsungan hidup ikan dapat dihitung dengan menggunakan rumus (Huisman 1987) :

$$
S R=\frac{N t}{N o} x 100 \%
$$

Keterangan :

SR : Survival Rate atau tingkat kelangsungan hidup (\%)

$\mathrm{Nt} \quad$ : Populasi saat t (ekor)

No : Populasi awal (ekor)

\section{Laju Pertumbuhan Spesifik Ikan}

Ikan disampling bobot rutin setiap 10 hari sekali. Pertumbuhan spesifik ikan (Specific Growth Rate / SGR) adalah besarnya laju pertumbuhan harian ikan. SGR dapat dihitung dengan menggunakan rumus (Huisman 1987) :

$$
S G R=\left[\sqrt[t]{\frac{W t}{W o}-1}\right] x 100 \%
$$

Keterangan :

SGR : Specific Growth Rate atau Laju pertumbuhan spesifik (\%/hari)

Wt : Berat rata-rata ikan pada saat akhir(gram)

Wo : Berat rata-rata ikan pada saat awal (gram)

$\mathrm{t} \quad$ : Lama pemeliharaan (hari)

\section{Konversi Pakan}

Konversi pakan (Food Convertion Ratio / FCR) dihitung dengan menggunakan rumus (Effendi 1997) :

$$
F C R=\frac{P a}{B t-B o+B m}
$$

Keterangan :

FCR : Konversi pakan

$\mathrm{Pa} \quad$ : Jumlah pakan yang diberikan (gram)

Bt : Bobot ikan akhir (gram)

Bo : Bobot ikan awal (gram)

Bm : Bobot ikan mati (gram)

\section{HASIL DAN PEMBAHASAN}

\section{Kepadatan Bakteri Total dan Bacillus spp. di Usus}

Kepadatan bakteri total dan Bacillus spp. di dalam usus ikan nila yang dipelihara dengan berbagai perlakuan adalah sebagai berikut (Tabel 1).

Tabel 1. Total bakteri dan Bacillus spp. di dalam usus ikan selama 45 hari pemeliharaan dengan berbagai perlakuan dosis probiotik dan prebiotik 


\begin{tabular}{|c|c|c|}
\hline Perlakuan & Total Bakteri (CFU/g) & Total Bacillus spp. (CFU/g) \\
\hline $\mathrm{K}$ & $2,24 \times 10^{8} \pm 3,29 \times 10^{7} \mathrm{c}$ & $1,07 \times 10^{6} \pm 1,57 \times 10^{5 c}$ \\
\hline A & $2,82 \times 10^{8} \pm 2,17 \times 10^{7} \mathrm{bc}$ & $1,60 \times 10^{7} \pm 1,23 \times 10^{6} b$ \\
\hline B & $3,43 \times 10^{8} \pm 2,31 \times 10^{7} \mathrm{ab}$ & $1,82 \times 10^{7} \pm 1,22 \times 10^{6} \mathrm{ab}$ \\
\hline $\mathrm{C}$ & $3,78 \times 10^{8} \pm 5,15 \times 10^{7 / \mathrm{a}}$ & $2,02 \times 10^{7} \pm 2,75 \times 10^{6} \mathbf{a}$ \\
\hline D & $3,69 \times 10^{8} \pm 1,19 \times 10^{7} \mathrm{a}$ & $2,00 \times 10^{7} \pm 6,47 \times 10^{5} \mathrm{a}$ \\
\hline
\end{tabular}

Total bakteri usus ikan selama pemberian perlakuan uji ditemukan berbeda nyata, dengan total bakteri tertinggi ditemukan pada perlakuan Bacillus spp. $20 \mathrm{ml} / \mathrm{Kg}$ pakan, baik yang tanpa pemberian prebiotik (molase) maupun dalam perlakuan sinbiotik (Bacillus spp. + molase). Adapun total bakteri terendah diperoleh dari perlakuan control, yaitu tanpa pemberian probiotik di dalam pakan. Hal ini menunjukkan bahwa pemberian probiotik dapat meningkatkan total bakteri usus pada ikan nila. Hasil ini sejalan dengan total bakteri usus pada ikan mas yang diberikan perlakuan sinbiotik, yaitu lebih tinggi secara signifikan dibandingkan perlakuan probiotik dan kontrol (Sari 2014).

Total bakteri usus yang ditemukan dalam penelitian ini memiliki korelasi positif dengan keberadaan Bacillus spp. di dalam usus ikan $(\mathrm{r}=0,9203)$, yaitu meningkat seiring dengan peningkatan total bakteri (Gambar 1). Bakteri Bacillus spp. yang digunakan dalam penelitian ini adalah bakteri yang diisolasi dari saluran pencernaan ikan nila sehingga dapat hidup dan menyesuaikan diri di dalam saluran pencernaan ikan nila. Kesarcodi-Watson et al. (2008), menyebutkan bahwa spesies bakteri probiotik sebaiknya merupakan mikroflora normal usus sehingga bakteri tersebut lebih mudah menyesuaikan diri dengan lingkungan usus dan dapat mencapai lokasi di mana efek dibutuhkan berlangsung. Berbagai jenis Bacillus sudah pernah diuji coba untuk menunjang pertumbuhan ikan, diantaranya $B$. subtilis (Efendi \& Yusra 2014; Dhanalakshmi et al. 2015; Abareethan \& Amsath 2015), B. pumilus (Rajikkannu et al. 2015), B. megaterium (Ochoa \& Olmos 2006), dan Lactobacillus spp. (Dhanalakshmi et al. 2015; Abareethan \& Amsath 2015).

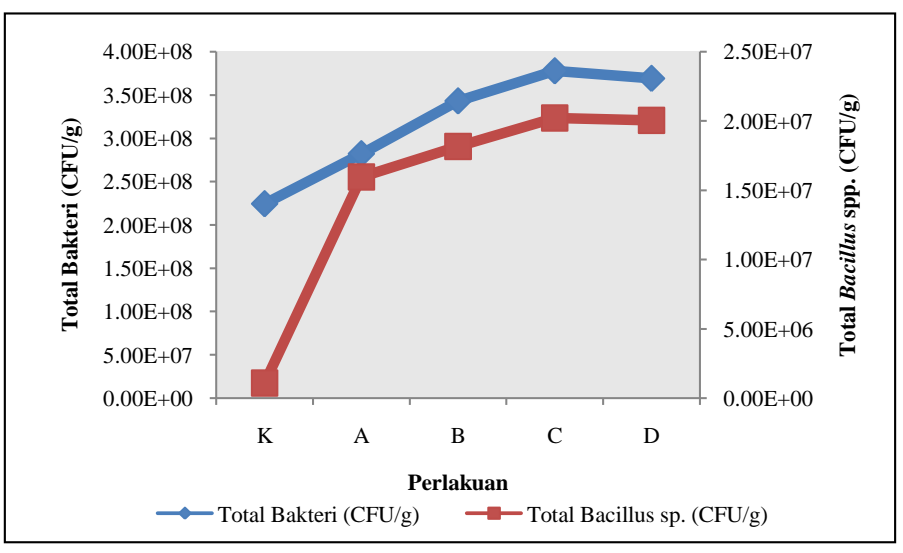

Gambar 1. Total bakteri dan Bacillus spp. di usus ikan nila.

Keterangan : Perlakuan (Kontrol (K); Bacillus spp. 10 ml/Kg pakan (A); Bacillus spp. $10 \mathrm{ml} / \mathrm{Kg}$ pakan + molase $10 \mathrm{v} / \mathrm{v}$ probiotik (B); Bacillus spp. 20 ml/Kg pakan (C); Bacillus spp. $20 \mathrm{ml} / \mathrm{Kg}$ pakan + molase $10 \mathrm{v} / \mathrm{v}$ probiotik (D)).

\section{Tingkat Kelangsungan Hidup}

Tingkat kelangsungan hidup ikan selama penelitian berlangsung ditemukan tidak berbeda nyata secara statistika $(p>0,05)$. Meski secara statistika tidak berbeda nyata, namun terlihat ada kecenderungan perlakuan probiotik $10 \mathrm{ml} / \mathrm{Kg}$ pakan dan $20 \mathrm{ml} / \mathrm{Kg}$ pakan, lebih rendah dibandingkan dengan perlakuan sinbiotik (Gambar 2). Hal ini sejalan dengan hasil penelitian yang dilakukan oleh Sari (2014) yang dilakukan pada ikan mas (Cyprinus carpio), yaitu ada kecenderungan ikan yang diberikan perlakuan sinbiotik memiliki tingkat kelangsungan hidup yang relatif lebih tinggi dibandingkan dengan perlakuan probiotik (Bacillus NP5). Hal ini diduga terkait dengan kemampuan saluran pencernaan ikan dalam menampung probiotik tanpa diimbangi dengan pemberian nutrisi khusus untuk bakteri tersebut.

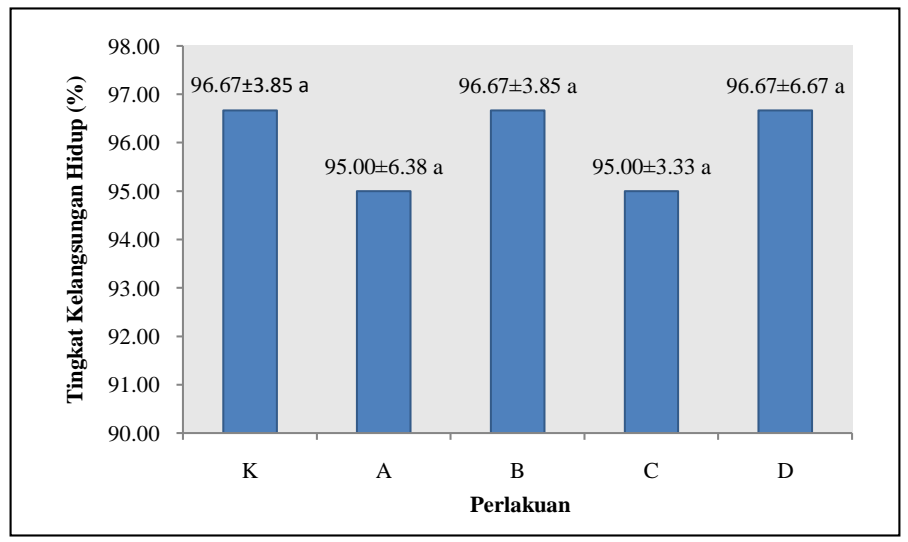

Gambar 2. Tingkat kelangsungan hidup ikan dengan perlakuan probiotik yang berbeda.

\section{Pertumbuhan dan Konversi Pakan}

Di dalam saluran pencernaan ikan terdapat berbagai jenis bakteri, banyak diantara bakteri tersebut yang berperan sebagai jasad pathogen. Bacillus spp. diketahui merupakan salah satu bakteri gram positif yang memiliki sifat menguntungkan bagi inang, karena dapat meningkatkan respon imun dan resisten terhadap infeksi bakteri pathogen, serta meningkatkan performa pertumbuhan (Buruina et al. 2014; Rajikkannu et al. 2015;Dhanalakshmi et al. 2015).

Pertumbuhan dan konversi pakan merupakan parameter penting dalam pengamatan ikan. Hasil 
pengamatan terhadap pertumbuhan dan konversi pakan (FCR) dalam penelitian ini ditemukan tidak berbeda nyata (P>0,05) (Tabel 2). Meski demikian, perlakuan Bacillus spp. $20 \mathrm{ml} / \mathrm{Kg}$ pakan + molase $10 \mathrm{v} / \mathrm{v}$ (Perlakuan D) memberikan pengaruh yang relatif lebih baik dibandingkan dengan perlakuan lainnya (Gambar 3). Hal ini terlihat dari nilai rata-rata pertumbuhan mutlak perlakuan tersebut yang paling tinggi, meski nilai laju pertumbuhan harian (\%) dan konversi pakan (FCR) tidak memiliki pola yang jelas.

Tabel 2. Pertumbuhan mutlak, laju pertumbuhan dan konversi pakan ikan yang diberikan perlakuan probiotik yang berbeda

\begin{tabular}{cccc}
\hline Perlakuan & Pertumbuhan Mutlak (g) & LPH (\%) & FCR \\
\hline K & $10,80 \pm 0,48$ a & $1,01 \pm 0,001$ a & $1,48 \pm 0,02$ a \\
A & $10,71 \pm 0,94$ a & $1,01 \pm 0,004$ a & $1,62 \pm 0,32$ a \\
B & $10,88 \pm 1,51$ a & $1,01 \pm 0,000$ a & $1,63 \pm 0,13$ a \\
C & $10,90 \pm 1,07$ a & $1,01 \pm 0,003$ a & $1,37 \pm 0,19$ a \\
D & $11,33 \pm 0,56$ a & $1,01 \pm 0,004$ a & $1,69 \pm 0,43$ a \\
\hline Keterangan : Perlakuan (Kontrol (K); Bacillus spp. 10 mlKg pakan (A); Bacillus spp. 10 mlKg pakan + molase 10 v/v \\
probiotik (B); Bacillus spp. 20 mlKg pakan (C); Bacillus spp. 20 mlKg pakan + molase 10 v/v probiotik (D)). Supercript \\
Notasi beda nyata dengan uji Tukey 5\%). LPH (Laju Pertumbuhan Harian). FCR (Foed Convertion Ratiolkonversi pakan).
\end{tabular}

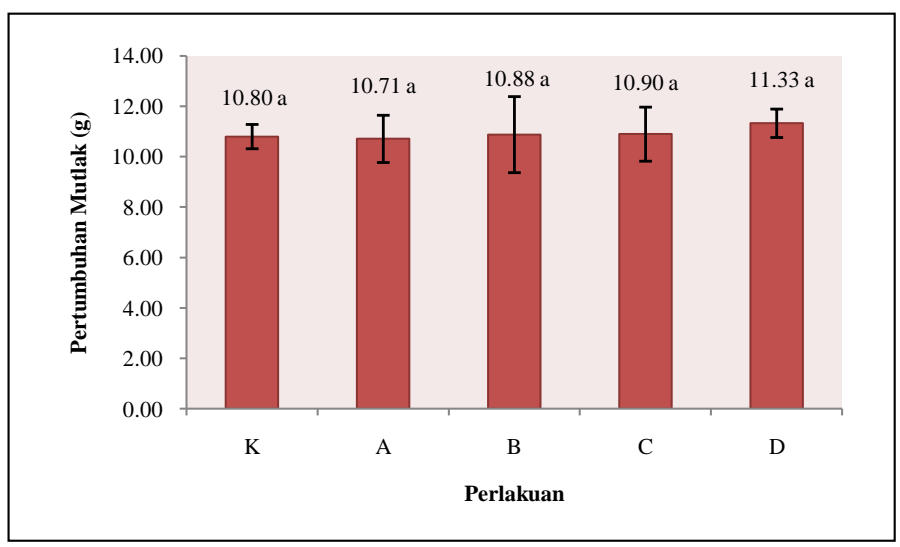

Gambar 3. Pertumbuhan mutlak ikan dengan perlakuan probiotik yang berbeda.

Efek baik bagi inang yang ditimbulkan oleh probiotik adalah menyesuaikan jumlah bakteri di dalam saluran pencernaan, memproduksi lactic acid (asam laktat) yang mampu meningkatkan afektivitas enzim dan membantu pencernaan makanan (Buruina et al. 2014). Meningkatnya metabolisme lemak karena peningkatan aktivitas enzim, salah satunya yaitu lipase, akan meningkatkan pemanfaatan pakan yang kaya lemak sebagai sumber energi. Sehingga konversi protein menjadi daging menjadi lebih optimal (Dhanalakshmi et al. 2015).

Lebih tingginya pertumbuhan mutlak pada perlakuan sinbiotik (Perlakuan D), dibandingkan perlakuan lainnya disebabkan karena sinergisme antara probiotik dan prebiotik, yang dapat meningkatkan regenerasi saluran pencernaan, dan meningkatkan fungsinya, sehingga dapat meningkatkan efektivitas enzim dan pada akhirnya akan meningkatkan pertumbuhan ikan (Abareethan \& Amsath 2015). Lebih lanjut lagi, keberadaan prebiotik dalam bentuk karbon sederhana dapat menunjang pertumbuhan bakteri di dalam saluran pencernaan sehingga tidak menjadi kompetitor dalam penyerapan energi dari nutrien pakan (Putra et al. 2015).

Pemberian Bacillus spp. dengan konsentrasi dan dosis yang tepat mampu meningkatkan jumlah sel darah merah dan kadar hemoglobin darah, hal ini diyakini sebagai salah satu indikator peningkatan kemampuan ikan dalam menyuplai nutrien ke suluruh tubuh dan perbaikan jaringan, sehingga dapat meningkatkan pertumbuhan ikan (Rajikkannu et al. 2015).

\section{KESIMPULAN DAN SARAN}

\section{Kesimpulan}

Kesimpulan yang dapat ditarik dari hasil dan pembahasan yang terbatas dalam penelitian ini adalah pemberian Bacillus spp. yang dikombinasikan dengan prebiotik molase dapat memberikan pengaruh yang menguntungkan, yaitu meningkatnya mikroflora (bakteri) usus dan pertumbuhan serta kelangsungan hidup ikan nila (Oreochromis niloticus).

\section{Saran}

Praktik penggunaan probiotik yang diberikan bersamaan dengan pakan dapat dilakukan dengan penambahan prebiotik sebagai nutrisi bagi bakteri probiotik tersbut.

\section{DAFTAR PUSTAKA}

Abareethan M. \& Amsath A. 2015. Characterization and evaluation of probiotic fish feed. International Journal of Pure and Applied Zoology, 3(2): 148153.

Bardach JE., Ryther JH. \& McLarney WO. 1972. Aquaculture. the Farming and Husbandry of Freshwater and Marine Organisms. John Wiley \& Sons.

Buruina CT., Profir AG. Vizireanu C. 2014EFFECTS OF PROBIOTIC BACILLUSSPECIES IN AQUACULTURE-AN OVERVIEW.The Annals of the University Dunarea de Jos of Galati Fascicle VI-Food Technology, 38(2): 9-17.

Dhanalakshmi G. Reniprabha A. \& Chandarakala A. 2015. Studies on the effcet of commercial probiotic 
application in the growthof the fish, Cyprinus carpio.International Journal of Advanced Research, 3(8): 708-712.

Effendi I. 2004. Pengantar Akuakultur. Depok (ID) : Penebar Swadaya.

Effendi H. 2000. Telaah Kualitas Air. Bogor (ID): IPB Press.

Efendi Y. \& Yusra. 2014. Bacillus subtilis strain VITNJ1 potential probiotic bacteria in the gut of Tilapia (Oreochromis niloticus) are cultured in floating net, Maninjau Lake, West Sumatra. Pakistan Journal of Nutrition, 13(12): 710-715.

Fuller R. 1992. History and Development of Probiotics. In Probiotics the Scientific Basis. Edited by Fuller. Chapman and Hall, London, New York, Melbourne. pp. 1-7.

Furuichi M. 1988. Dietary Requirements, p.8-78. In Watanabe, T, ed. Fish Nutrition andMarinculture. Departement of Aquatic Bioscience. Tokyo University of Fisheries. JICA.

Gibson GR., Probert HM., Loo JV., Rastall RA. \& Roberfroid MB. 2004. Dietary modulation of the human colonicmicrobiota: updating the concept of prebiotics. Nutr. Res. Rev., 17(2): 259-275.

Gullian M., Thompson F. \& Rodriguez J. 2004. Selection of probiotic bacteria and study of their immunostimulatory effect in Pennaeus vannamei. Aquaculture, 233: 1-14.

Hadadi A., Herry., Setyorini E. \& Ridwan. 2007. Pemanfaatan limbah sawit untuk bahan baku pakan ikan. Jurnal Budidaya Air Tawar, 4: 11-12.

Halver JE. \& Hardy RW. 2002. Fish Nutrition. $3^{\text {rd }}$ ed. Acad. Press, Amsterdam. 822p.

Huisman EA. 1987. Principles of fish production. Department of Fish Culture and Fisheries, Wageningen Agriculture University. Wageningen. Netherland. 170p.

Khairuman D., Sudenda \& B. Gunadi, 2008. Budidaya Ikan Mas secara Intensif(Revisi). Jakarta (ID): PT. Agromedia Pustaka.
Kesarcodi-Watson A., Kaspar H., Lategan J. \& Gibson L. 2008. Probiotics in aquaculture : The need, principles and mechanisms of action and screening processes. Aquaculture, 274: 1-14.

Lazado CC. \& Caipang CMA. 2014. Mucosal immunity and probiotics in fish. Fish \& Shellfish Immunology, 39: 78-89.

Lisal JS. 2005. Konsep Probiotik dan Prebiotik untuk Modulasi Mikrobita Usus Besar. Medical Nusantara, 26: Oktober-Desember.

Nayak SK. 2010. Probiotics and immunity: A fish perspective. Fish \& Shellfish Immunology, 29: 214.

Ocha S. \& Olmos S. 2006. The functional property of Bacillus for shrimp feeds. Aquaculture, 23: 519525.

Putra AN., Utomo NBP. \& Widanarni. 2015. Growth Performance of Tilapia (Oreochromis niloticus) Fed with Probiotic, Prebiotic and Synbiotic in Diet. Pakistan Journal of Nutrition, 14(5): 263 268.

Rajikkannu M., Natarajan N., Santhanam P., Deivasigamani B., Ilamathi J. \& Janani S. 2015. Effect of probiotics on the haematological parameters of Indian major carp (Labeo rohita). International Journal of Fisheries and Aquatic Studies, 2(5): 105-109.

Ramadanil. 1994. Penggunaan Limbah Batang Pisang sebagai Substrat oleh Trichoderma viride Pers T04 dan Penicillium vermiculatum Dangeard 9AA1[Tesis]. Bandung (ID). Institut Teknologi Bandung.

Rengpipat S., Rukpratanporn S., Piyatitivorakul S. \& Menasaveta P. 1998b. Effect of probiotic bacterium on black tiger shrimp Penaeus monodon survival and growth. Aquaculture, 167:301-313.

Ringo E., Olsen RE., Gifstad TTO., Dalmo RA., Amlund H., Hemre GL. \& Bakke AM. 2010. Prebiotics in aquaculture: a review. Aquaculture Nutrition, 16: 117-136.

Saavedra JM., Bauman NA., Oung I., Perman JA. \& Yolken RH. 1994. Feeding ofBifidobacterium 
bifidum and Streptococcus thermophillus to infants in hospitalfor prevention of diarrhoea and shedding of rotavirus. Lancer, 344: 1046-1049.

Safitri R. 2010. Medium Analisis Mikroorganisme. Bandung (ID): CV. Trans Info Media.

Sari DN. 2014. Aplikasi Probiotik, Prebiotik dan Sinbiotik melalui Pakan untuk Pencegahan Infeksi Aeromonas hydrophila pada Ikan Mas Cyprinus carpio [Skripsi]. Bogor (ID): Institut Pertanian Bogor.

Schrezemeir J. \& Vrese M. 2001. Probiotics, prebiotics and sinbiotics-approaching definition. American Journal of Clinical Nutrition, 73(2): 361-364.

Takeuchi T. 1988. Laboratory Work Chemical Evaluation of Dietary Nutrition In Watanabe T. Fish Nutrition and Mariculture JICA Textbook the General Aquaculture Course. Tokyo : Kanagawa International Fisheries Training Center.

Verschuere L., Rombaut G., Sorgeloos P. \& Verstraete W. 2000. Probiotic bacteria as biological control agents in aquaculture. Journal of Microbiology and Molecular Biology, 64: 655-671.

Wang YB., Li JR. \& Lin J. 2008. Probiotics in aquaculture: challenges and outlook.Aquaculture, 281: 1-4.

Wikipedia. 2015a. Ikan Nila. http://id.wikipedia.org/wiki/ikan_nila.html. [diakses 29 Maret 2015]

Wikipedia. 2015b. Molase. http://id.wikipedia.org/wiki/molase.html. [diakses 30 November 2015]

Zhou X., Wang Y. \& Li W., 2009. Effect of probiotic on larvae shrimp (Penaeus vannamei) based on water quality, survival rate and digestive enzyme activities. Aquaculture, 287: 349-353. 